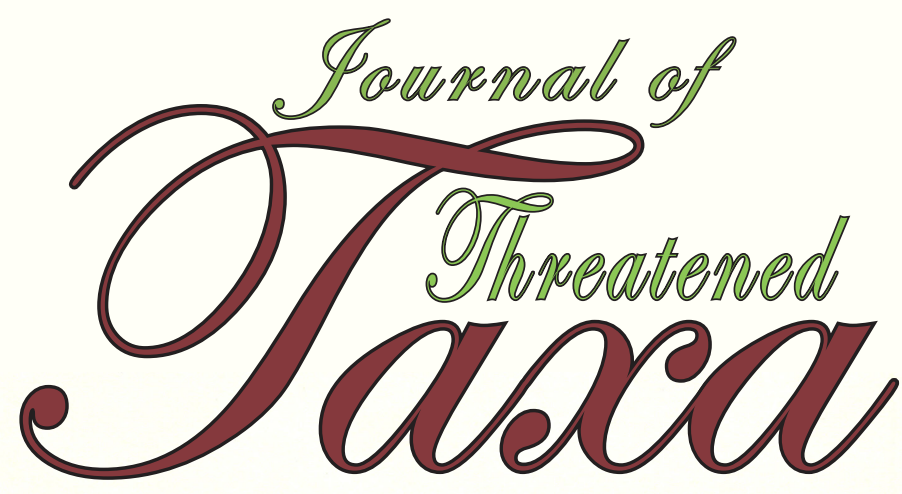

10.11609/jott.2021.13.14.20143-20310 enever.threatenedtaxa.org

26 December 2021 (Online \& Print) Val. 13 | Na. 14 | Pages: 20143-20310 155n 0974-7907 (Online) 155n 0974-7893 (Print)

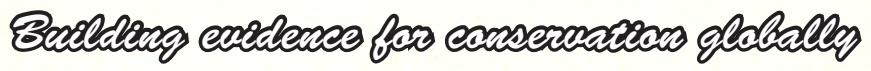

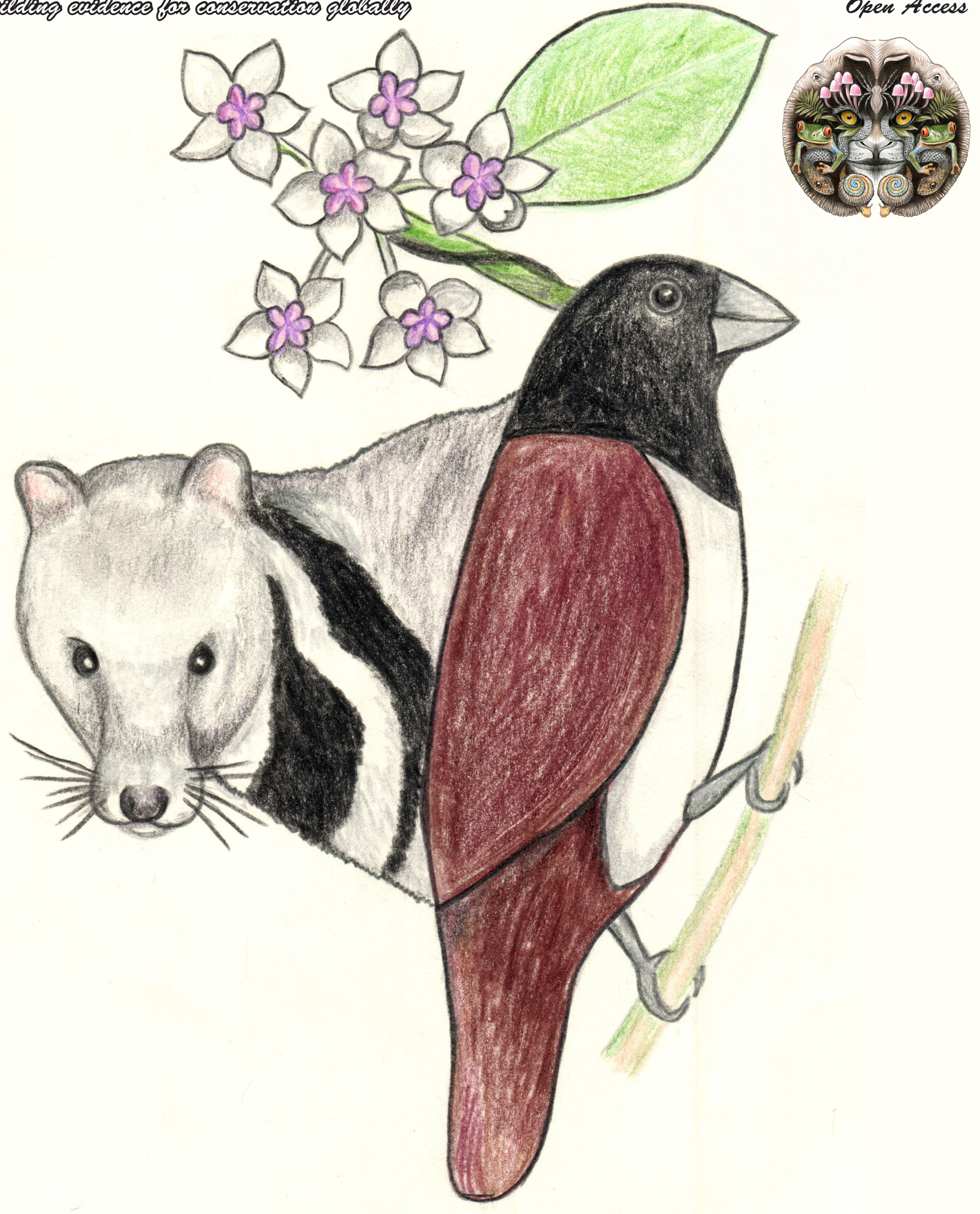

Open Access 


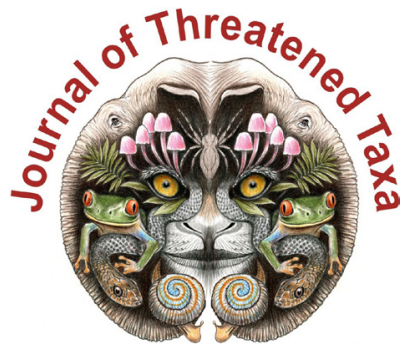

ISSN 0974-7907 (Online); ISSN $0974-7893$ (Print)

Publisher

Host

Wildlife Information Liaison Development Society

www.wild.zooreach.org

Zoo Outreach Organization www.zooreach.org

No. 12, Thiruvannamalai Nagar, Saravanampatti - Kalapatti Road, Saravanampatti, Coimbatore, Tamil Nadu 641035, India

Ph: +91 9385339863 | www.threatenedtaxa.org

Email: sanjay@threatenedtaxa.org

EDITORS

\section{Founder \& Chief Editor}

Dr. Sanjay Molur

Wildlife Information Liaison Development (WILD) Society \& Zoo Outreach Organization (ZOO),

12 Thiruvannamalai Nagar, Saravanampatti, Coimbatore, Tamil Nadu 641035, India

\section{Deputy Chief Editor}

Dr. Neelesh Dahanukar

Noida, Uttar Pradesh, India

\section{Managing Editor}

Mr. B. Ravichandran, WILD/ZOO, Coimbatore, India

\section{Associate Editors}

Dr. Mandar Paingankar, Government Science College Gadchiroli, Maharashtra 442605, India

Dr. Ulrike Streicher, Wildlife Veterinarian, Eugene, Oregon, USA

Ms. Priyanka lyer, ZOO/WILD, Coimbatore, Tamil Nadu 641035, India

Dr. BA. Daniel, $200 / \mathrm{WILD}$, Coimbatore, Tamil Nadu 641035, India

\section{Editorial Board}

Dr. Russel Mittermeie

Executive Vice Chair, Conservation International, Arlington, Virginia 22202, USA

\section{Prof. Mewa Singh Ph.D., FASc, FNA, FNASc, FNAPsy}

Ramanna Fellow and Life-Long Distinguished Professor, Biopsychology Laboratory, and Institute of Excellence, University of Mysore, Mysuru, Karnataka 570006, India; Honorary Professor, Jawaharlal Nehru Centre for Advanced Scientific Research, Bangalore; and Adjunct Professor, National Institute of Advanced Studies, Bangalore

\section{Stephen D. Nash}

Scientific Illustrator, Conservation International, Dept. of Anatomical Sciences, Health Sciences Center, T-8, Room 045, Stony Brook University, Stony Brook, NY 11794-8081, USA

\section{Dr. Fred Pluthero}

Toronto, Canada

\section{Dr. Priya Davidar}

Sigur Nature Trust, Chadapatti, Mavinhalla PO, Nilgiris, Tamil Nadu 643223, India

\section{Dr. Martin Fisher}

Senior Associate Professor, Battcock Centre for Experimental Astrophysics, Cavendish

Laboratory, JJ Thomson Avenue, Cambridge CB3 OHE, UK

\section{Dr. John Fellowes}

Honorary Assistant Professor, The Kadoorie Institute, 8/F, T.T. Tsui Building, The University of Hong Kong, Pokfulam Road, Hong Kong

\section{Prof. Dr. Mirco Solé}

Universidade Estadual de Santa Cruz, Departamento de Ciências Biológicas, Vice-coordenado do Programa de Pós-Graduação em Zoologia, Rodovia Ilhéus/Itabuna, Km 16 (45662-000)

Salobrinho, Ilhéus - Bahia - Brasil

\section{Dr. Rajeev Raghavan}

Professor of Taxonomy, Kerala University of Fisheries \& Ocean Studies, Kochi, Kerala, India

\section{English Editors}

Mrs. Mira Bhojwani, Pune, India

Dr. Fred Pluthero, Toronto, Canad

Mr. P. Ilangovan, Chennai, India

Web Development

Mrs. Latha G. Ravikumar, ZOO/WILD, Coimbatore, India

\section{Typesetting}

Mr. Arul Jagadish, ZOO, Coimbatore, India

Mrs. Radhika, ZOO, Coimbatore, India

Mrs. Geetha, ZOO, Coimbatore India
Fundraising/Communications

Mrs. Payal B. Molur, Coimbatore, India

Subject Editors 2018-2020

Fungi

Dr. B. Shivaraju, Bengaluru, Karnataka, India

Dr. R.K. Verma, Tropical Forest Research Institute, Jabalpur, India

Dr. Vatsavaya S. Raju, Kakatiay University, Warangal, Andhra Pradesh, India

Dr. M. Krishnappa, Jnana Sahyadri, Kuvempu University, Shimoga, Karnataka, India

Dr. K.R. Sridhar, Mangalore University, Mangalagangotri, Mangalore, Karnataka, India

Dr. Gunjan Biswas, Vidyasagar University, Midnapore, West Bengal, India

\section{Plants}

Dr. G.P. Sinha, Botanical Survey of India, Allahabad, India

Dr. N.P. Balakrishnan, Ret. Joint Director, BSI, Coimbatore, India

Dr. Shonil Bhagwat, Open University and University of Oxford, UK

Prof. D.J. Bhat, Retd. Professor, Goa University, Goa, India

Dr. Ferdinando Boero, Università del Salento, Lecce, Italy

Dr. Dale R. Calder, Royal Ontaro Museum, Toronto, Ontario, Canada

Dr. Cleofas Cervancia, Univ. of Philippines Los Baños College Laguna, Philippines

Dr. F.B. Vincent Florens, University of Mauritius, Mauritius

Dr. Merlin Franco, Curtin University, Malaysia

Dr. V. Irudayaraj, St. Xavier's College, Palayamkottai, Tamil Nadu, India

Dr. B.S. Kholia, Botanical Survey of India, Gangtok, Sikkim, India

Dr. Pankaj Kumar, Kadoorie Farm and Botanic Garden Corporation, Hong Kong S.A.R., China

Dr. V. Sampath Kumar, Botanical Survey of India, Howrah, West Bengal, India

Dr. A.J. Solomon Raju, Andhra University, Visakhapatnam, India

Dr. Vijayasankar Raman, University of Mississippi, USA

Dr. B. Ravi Prasad Rao, Sri Krishnadevaraya University, Anantpur, India

Dr. K. Ravikumar, FRLHT, Bengaluru, Karnataka, India

Dr. Aparna Watve, Pune, Maharashtra, India

Dr. Qiang Liu, Xishuangbanna Tropical Botanical Garden, Yunnan, China

Dr. Noor Azhar Mohamed Shazili, Universiti Malaysia Terengganu, Kuala Terengganu, Malaysia

Dr. M.K. Vasudeva Rao, Shiv Ranjani Housing Society, Pune, Maharashtra, India

Prof. A.J. Solomon Raju, Andhra University, Visakhapatnam, India

Dr. Mandar Datar, Agharkar Research Institute, Pune, Maharashtra, India

Dr. M.K. Janarthanam, Goa University, Goa, India

Dr. K. Karthigeyan, Botanical Survey of India, India

Dr. Errol Vela, University of Montpellier, Montpellier, France

Dr. P. Lakshminarasimhan, Botanical Survey of India, Howrah, India

Dr. Larry R. Noblick, Montgomery Botanical Center, Miami, USA

Dr. K. Haridasan, Pallavur, Palakkad District, Kerala, India

Dr. Analinda Manila-Fajard, University of the Philippines Los Banos, Laguna, Philippines

Dr. P.A. Sinu, Central University of Kerala, Kasaragod, Kerala, India

Dr. Afroz Alam, Banasthali Vidyapith (accredited A grade by NAAC), Rajasthan, India

Dr. K.P. Rajesh, Zamorin's Guruvayurappan College, GA College PO, Kozhikode, Kerala, India

Dr. David E. Boufford, Harvard University Herbaria, Cambridge, MA 02138-2020, USA

Dr. Ritesh Kumar Choudhary, Agharkar Research Institute, Pune, Maharashtra, India

Dr. Navendu Page, Wildlife Institute of India, Chandrabani, Dehradun, Uttarakhand, India

\section{Invertebrates}

Dr. R.K. Avasthi, Rohtak University, Haryana, India

Dr. D.B. Bastawade, Maharashtra, India

Dr. Partha Pratim Bhattacharjee, Tripura University, Suryamaninagar, India

Dr. Kailash Chandra, Zoological Survey of India, Jabalpur, Madhya Pradesh, India

Dr. Ansie Dippenaar-Schoeman, University of Pretoria, Queenswood, South Africa

Dr. Rory Dow, National Museum of natural History Naturalis, The Netherlands

Dr. Brian Fisher, California Academy of Sciences, USA

Dr. Richard Gallon, llandudno, North Wales, LL30 1UP

Dr. Hemant V. Ghate, Modern College, Pune, India

Dr. M. Monwar Hossain, Jahangirnagar University, Dhaka, Bangladesh

Mr. Jatishwor Singh Irungbam, Biology Centre CAS, Branišovská, Czech Republic.

Dr. Ian J. Kitching, Natural History Museum, Cromwell Road, UK

Dr. George Mathew, Kerala Forest Research Institute, Peechi, India

For Focus, Scope, Aims, and Policies, visit https://threatenedtaxa.org/index.php/JoTT/aims_scope
For Article Submission Guidelines, visit https://threatenedtaxa.org/index.php/JoTT/about/submissions
For Policies against Scientific Misconduct, visit https://threatenedtaxa.org/index.php/JoTT/policies_various 


\title{
Crop and property damage caused by Purple-faced Langurs Trachypithecus vetulus (Mammalia: Primates: Cercopithecidae)
}

\author{
Vincent Nijman (1D \\ School of Social Sciences, Oxford Brookes University, Gipsy Lane, Oxford OX3 OBP, UK. \\ vnijman@brookes.ac.uk
}

Sri Lanka is an excellent area to study the relationships between Humans Homo sapiens and commensal primates: the island is home to slender lorises, macaques and langurs and, for the last 40,000 years or so, humans (Nekaris \& de Silva Wijeyeratne 2007; Nijman \& Nekaris 2013). The extensive presence of home gardens, mimicking the forest structure by adopting different layers, allows primates to come into close contact with humans, and the predominant religions adopted by Sri Lankans may facilitate a peaceful co-existence (cf. Rudran 2008; Rudran et al. 2021). Repeated crop-raiding and conflict over space, however, may cause people to become increasingly intolerant to primates.

Wijethilaka et al. (2021) lamented the small number of reports on conflicts between Humans and Western Purple-faced Langur Trachypithecus vetulus nestor. In their introduction and discussion Wijethilaka et al. (2021) refer to a large number of studies that report on Human-primate conflict and crop-raiding involving a wide range of primate species, including Chimpanzees Pan troglodytes, Olive Baboons Papio anubis, Redtailed Monkeys Cercopithecus ascanius, Vervet Monkeys Chlorocebus pygerythrus, Rhesus Macaques Macaca mulatta, Hanuman Langurs Semnopithecus entellus, and Bonnet Macaques Macaca radiata. What they overlooked were those studies that had been conducted on Western Purple-faced Langurs. To rectify this and to provide the reader of the Journal of Threatened Taxa with a more complete (chronological) overview I here give brief summaries of the outcomes of these studies and how they concur or contrast with that reported by Wijethilaka et al. (2021).

Wijethilaka et al. (2021) evaluated the intensity of Human-langur conflict through the identification of the crop and property damages caused by these langurs. Their assessment was based on interviews with 80 households in villages bordering Danawkanda Forest in western Sri Lanka collected over a six-month period in 2014-2015. They also quantified the loss (financial and otherwise) reportedly incurred to these households. Over $90 \%$ of the interviewees indicated that the damage had been done to commercially important plants (primarily Banana Musa paradisiaca, Papaya Carica papaya, Rambutan Nephelium lappaceum and Mango Mangifera indica). Three-quarter reported damage of roof tiles and over $40 \%$ reported having had frightful encounters with the langurs. Wijethilaka et al. (2021) found a strong negative correlation between the amount of money spent on firecrackers (a proxy for the intensity of crop raiding and used by $99 \%$ of the interviewees) 
Table 1. Non-exhaustive overview of research conducted on Purple-faced Langurs (sometimes in addition to other primates or vertebrates). Researcher(s) only list one of the main persons involved, but it is acknowledged that the team often comprised more people. Dates in Italics indicate periodic monitoring or intermittent studies with gaps of up to two years. Ethnoprimatology includes studies on crop-raiding and humanwildlife conflict. Methods for ethnoprimatological studies: A-direct observation of langurs and people | B-interviews and questionnaires | C-workshops.

\begin{tabular}{|c|c|c|c|c|c|}
\hline Period & Researcher(s) & Location & Topics studied & Methods & Example reference \\
\hline ii 1968-iv 1970 & R. Rudran & $\begin{array}{l}\text { Horton Plains, } \\
\text { Polonnaruwa }\end{array}$ & Ecology, behaviour & & Rudran 1973 \\
\hline iii 1969-ii 1970 & C.M. Hladik & Polonnaruwa & Ecology & & Hladik 1977 \\
\hline ii 1985-ii 1987 & J.D.S. Dela & Piliyanadala, Panadura & Ecology, behaviour & & Dela 2007 \\
\hline iii 1987-xii 2006 & J.D.S. Dela & Piliyanadala, Panadura & $\begin{array}{l}\text { Ecology, behaviour, } \\
\text { ethnoprimatology }\end{array}$ & $A, B$ & Dela 2011 \\
\hline 1998-2018 & W.P.J. Dittus & Polonnaruwa & Ethnoprimatology & $A, B, C$ & Dittus et al. 2019 \\
\hline vi 2000-xii 2001 & P. Jayasekara & Sinharaja & Behaviour & & Jayasekara et al. 2007 \\
\hline v 2001-vii 2010 & K.A.I. Nekaris & Island-wide & Ethnoprimatology & $A, B, C$ & Nekaris et al. 2013 \\
\hline ? 2004-ii 2007 & C.A.D. Nahallage & Island-wide & Ethnoprimatology & $A, B$ & Nahallage et al. 2008 \\
\hline vi 2004-vii 2008 & R.S. Moore & Talangama, Masmullah & $\begin{array}{l}\text { Ecology, behaviour, } \\
\text { ethnoprimatology }\end{array}$ & $A, B$ & Douglas et al. 2008 \\
\hline vi-vii 2007 & R. Rudran & West & Ethnoprimatology & $A, B$ & Rudran 2008 \\
\hline vii 2008-xi 2009 & R.P. Vandercone & Kaludiyapokuna & Ecology, behaviour & & Vandercone et al. 2012 \\
\hline vi 2009-xii 2010 & R. Rudran & Waga & Ecology, behaviour & & Rudran et al. 2008 \\
\hline vii 2014-i 2015 & S. Wijethilaka & Danawkanda & Ethnoprimatology & B & Wijethilaka et al. 2021 \\
\hline i 2015-ix 2016 & C.A.D. Nahallage & Mihintale & $\begin{array}{l}\text { Ecology, behaviour, } \\
\text { ethnoprimatology }\end{array}$ & B & Kumara et al. 2019 \\
\hline ii 2015-iii 2019 & R. Rudran & Island-wide & Ethnoprimatology & $B, C$ & Cabral et al. 2018 \\
\hline iv-xi 2016 & $\begin{array}{l}\text { W.A.D.S.N. } \\
\text { Weerakkody }\end{array}$ & Delkanda, Homagama & Ecology & & Weerakkody et al. 2018 \\
\hline v-vii 2018 & C.A.D. Nahallage & Mihintale & Ethnoprimatology & B & Westwood 2018 \\
\hline
\end{tabular}

and the distance between Danawkanda Forest and the interviewees' residence or fields. The research I refer to that also reports on crop and property damage caused by Western Purple-faced Langurs was based on interviews, similar to Wijethilaka et al. (2021), workshops, direct observations, and often a combination of these methods (Table 1).

In their 'Primates of Sri Lanka', Nekaris \& de Silva Wijeyeratne (2007), based on extended periods of fieldwork in western Sri Lanka, noted specifically for the Western Purple-faced Langur that because the animals eventually come into contact with people, conflict is inevitable. This conflict mainly involved crop raiding (primarily of fruit trees) and using rooftops as 'runways' and thereby damaging the tiles. Interviews with local people showed that conflict was greatest in areas with the largest populations (of langurs), and in particular with those people who came into daily contact with the langurs. They noted that conflict can be so severe that landowners may shoot the langurs (Nekaris \& de Silva Wijeyeratne 2007).

Parker et al. (2008) conducted 735 interviews throughout the range of the Western Purple-faced
Langur. At the village level, estimates of local langur population size (by means of counting langurs directly as well as interviews) did not correlate with positive or negative perceptions towards langurs but the proportion of interviewees that held negative views towards the langurs was correlated with the time the langurs spent in their gardens and farmland (more time equates to more negative feelings). A quarter of all interviewees considered the langurs a nuisance, primarily because, just as in Wijethilaka et al.'s study, of the langurs raiding on Jackfruit Arctocarpus heterophylus, Rambutan, Banana and Mango. Destruction of roof tiles was reported as a problem. Several deterrents were used by the interviewees to drive langurs from their land, including throwing stones, shouting or setting dogs on them, and using firecrackers. Nijman \& Nekaris (2008) noted that the Western Purple-faced Langur appeared to be largely dependent on fruit grown in traditional home gardens, making the langurs almost wholly dependent on the tolerance of local people. With increasing urbanization, perceptions by local people of the langurs had changed for the worse. Negative attitudes towards the langurs increased with the amount of time langurs spend in 
close proximity to people. Besides the loss of habitat, attacks on langurs by landowners' and stray Dogs Canis familiaris add another source of mortality, and the need for arboreal continuity has put them into lethal contact with electric power lines in this urban domain.

Eschmann et al. (2008) and Moore et al. (2010), over a seven-month period, studied five groups of Western Purple-faced Langur and Humans in a suburban area in Talangama, where the langur's homeranges completely overlapped with Human living space. Twelve of the thirteen trees most used for feeding by the langurs were also used by Humans, with Jack Fruit, Mangos and Rambutans topping the list. They noted that when langurs crossed rooftops of occupied houses, the owners often chased them away or complained about damage the langurs caused. The most common methods to chase the langurs out of feeding trees or off rooftops were using firecrackers followed by throwing stones. Eschmann et al. (2008) reported that to the meagre canopy continuity in Talangama exposed much of the langurs' homeranges to direct sunlight. While this in turn led to the langurs to start calling earlier in the morning compared to groups living in forests, overall Eschmann et al. (2008) found the langurs to be remarkably desensitised to the effects of most Human activities.

Nijman \& Nekaris (2010) analysed data from 48 interviewees from villages with and without forest in its vicinity and found that the intensity of conflict, and especially reports of the killing of langurs, was higher in villages where the forest was no longer present. The amount of forest and trees buffers against the need to feed on Human-grown foods or the use of man-made structures as arboreal pathways.

Of all the studies reported here, the one by Dela (2011) is most closely aligned to that of Wijethilaka et al. (2021) in terms of methodology, results, and conclusions. In 1987, she conducted a questionnaire survey with 112 participants in Panadura and Piliyandalawhere where she also studied the langurs (Dela 2007). Roof and crop damage were the most frequently cited damage (64\% and $23 \%$ of interviewees, respectively) and conflict was most prominent when the langurs fed on Mango, Banana and Bread Fruit $A$. incisus. Two-thirds of the interviewees resorted to making loud noises (firecrackers, shouting) and one third to throwing stones or using slingshots or catapults to deter crop raiding. When corrected for inflation to June 2021, the distribution of household income in Dela's (2011) study was similar to that of Wijethilaka et al. (2021), with $~ 80 \%$ of people earning less than US\$160-180 month $^{-1}$. While the desire to destroy langurs was higher in households with an income of over
US\$160 month $^{-1}$ compared to those that earned less (i.e., $12.5 \%$ vs $6.2 \%$ ) the difference was not statistically significant (Dela 2011). Dela's (2011) is one of the most comprehensive study on how the perceptions and real day-to-day experiences of people have an effect of on both the langur's habitat and the langurs themselves and her findings and conclusions, despite being partially based on a survey conducted over three decades ago, ring true to this day.

Nijman and Nekaris (2013) advocated the adoption an ethnographic perspective as this would allow for mitigation policies to be defined with regard to a local cultural context in which traditions and religious parameters often exist for the preservation or to the detriment of wildlife. Based on 182 days of observations of langurs (and Toque Macaques $M$. sinica) and an interview survey of 1,036 people they assessed levels of conflict between Humans and primates both in an agricultural and urban context. With respect to the Western Purple-faced Langur they found generally high levels of tolerance in both settings, but high levels of crop-raiding along the forest edge and frequent use of roofs as part of arboreal pathways caused discontent. They concluded that a heavy reliance on fruit by otherwise folivorous langurs may compromise their dietary needs and parasite loads of commensal primates were suspected to be unhealthily high.

Weerakkody et al. (2018) found that in urban and semi-urban landscapes the homerange size of Western Purple-faced Langurs is both determined by the resource base (e.g., the number of fruiting trees) and impassable boundaries (rice fields, houses); these anthropogenetic factors hinder the movement of the arboreal langurs across the landscape, and may explain the proximate causes of Human-langur conflict.

Rudran et al. (2020b) addressed in detail and with great consideration how to deal the issue of engaging local communities in the conservation of Western Purple-faced Langurs at a time when the people are facing difficulties caused by the conflicts with the langurs. While they did not present new data on crop or property damage caused by the langurs, the solutions they offer are relevant to the challenges highlighted by Wijethilaka et al. (2021). Finally, for completeness I will discuss Rudran et al. (2021) who reported on a mitigating Human-primate conflict study by means of interviewing people from 11 districts in Sri Lanka. This paper appeared after the publication of Wijethilaka et al. (2021) but data collection for this study had commenced only one year after Wijethilaka et al. (2021) had finished collecting theirs (viz., it ran from January 
2016 to June 2018). While Rudran et al. (2021)'s study covered all three diurnal primate species, some of their data can be attributed to Western Purple-faced Langurs as it specifies data for Colombo District. Of the 147 people interviewed in Colombo, $70 \%$ were Buddhist and $8 \%$ Hindu. In contrast to reports by Wijethilaka et al. (2021) levels of tolerance towards Western Purplefaced Langurs was high (ranked 4.3 on a scale from 1 to 6) something that Rudran et al. (2021) attributed to the majority of interviewees practising Buddhism which preaches compassion to all living beings. The reported monthly cost, corrected for inflation to June 2021, of damage due to Western Purple-faced Langur and Toque Macaques in Colombo ranged from less than US\$2.79 (19\% of respondents), US\$2.80-5.59 (36\%), US\$5.60$27.96(28)$ to more than US\$27.97 (16\%). This is within the same range as the monthly average of US\$10.0518.10 reported by Wijethilaka et al. (2021).

The overview presented here demonstrate that a great deal is known conflict between Humans and Western Purple-faced Langurs. This is not surprising as arguably the Purple-faced Langur is among the most thoroughly studied colobine monkeys globally (Table 1). It is also clear that over time there has been a shift in research focus from purely ecology and behaviour of the langurs in the 1970s to 1990s to a mixture of ecology and behaviour, and ethnoprimatology during the last two decades (Table 1). There is a great level of concordance between the data from Danawkanda and that from Panadura, Piliyandala and Talangama, and indeed other sites. What remains unanswered are the possible underlying factors for the apparent differences. For instance, Wijethilaka et al. (2021) make no mention of langurs being electrocuted or killed by dogs, while this did come up prominently in the studies of Parker et al. (2008), Nijman \& Nekaris (2008), Moore et al. (2010), Dela (2011) and indeed Rudran (2008), and Nahallage et al. (2008). It is possible that there are no dogs in Danawkanda (or no dog large enough to do harm to Purple-faced Langurs), and perhaps there are still enough natural arboreal pathways for the langurs to use so they can avoid powerlines (it is even possible that there are no powerlines), but a proper comparison by Wijethilaka et al. (2021) of their data with that collected by others could have made that clear. Shooting at Purple-faced Langurs with air-rifles or pellet guns is also commonly mentioned -Wijethilaka et al. (2021) pooled this with the use of catapults and reported that $18 \%$ of household in Danawkanda used this method- but there seems to be significant variations in its frequency. In 2011 the Ministry of Coconut Development and State Plantations as well as local Directors of Planning, endorsed the idea of issuing air rifles to farmers and planters to ward off primates and Common Giant Squirrel Ratufa macroura from damaging their crops (Rodrigo 2011; Sugathapala \& Wijeweera 2011; Dittus et al. 2019), but at present it is unclear what the uptake of this has been and the effects it has on Purple-faced Langurs.

In conclusion, despite the langur's small area of occupancy $\left(2,000 \mathrm{~km}^{2}\right)$ and its small population size (Rudran et al. 2020b) I find that over the last decades a number of studies have been published on the interactions between Humans and Western Purplefaced Langurs (Table 1), the perceptions that people have towards the langurs, especially in (semi-)urbanised areas, and how to best mitigate any negative effects of having langurs and people living in close proximity. For primate conservation to work in Sri Lanka sharing space with monkeys and ensuring levels of Human tolerance towards primates remain high is paramount (in addition to having enough areas set aside specifically for primates and other wildlife: Dittus et al. 2021). The findings by Wijethilaka et al. (2021) in terms of the proportion of people that report crop damage or damage to roofs is high in comparison with earlier studies, which may reflect a decrease in tolerance towards the langurs, differences in methodology or it may reflect random geographical differences.

\section{References}

Cabral, S.J., T. Prasad, T.P. Deeyagoda, S.N. Weerakkody, A. Nadarajah \& R. Rudran (2018). Investigating Sri Lanka's human-monkey conflict and developing a strategy to mitigate the problem. Journal of Threatened Taxa 10: 11391-11398. https://doi.org/10.11609/ jott.3657.10.3.11391-11398

Dela, J.D. (2011). Impact of monkey-human relationships and habitat change on Semnopithecus vetulus nestor in human modified habitats. Journal of the National Science Foundation of Sri Lanka 39: 365-382. https://doi.org/10.4038/jnsfsr.v39i4.4144

Dela, J.D.S. (2012). Seasonal food use strategies of Semnopithecus vetulus nestor, at Panadura and Piliyandala, Sri Lanka. International Journal of Primatology 28: 607-626. https://doi.org/10.1007/ s10764-011-9538-3

Dittus, W.P., S. Gunathilake \& M. Felder (2019). Assessing public perceptions and solutions to human-monkey conflict from 50 years in Sri Lanka. Folia Primatologica 90: 89-108. https://doi. org/10.1159/000496025

Dittus, W.P., S. Gunathilake \& M. Felder (2021). Sharing space with monkeys and human tolerance are critical supplements to primate conservation, but not substitutes for protected nature reserves: a long-term view from Sri Lanka. Folia Primatologica 92: (in press).

Douglas, P.H., R.S. Moore, S. Wimalasuriya, A. Gunawardene \& K.A.I. Nekaris (2008). Microhabitat variables influencing abundance and distribution of diurnal primates (Trachypithecus vetulus vetulus and Macaca sinica aurifrons) in a fragmented rainforest network in southern Sri Lanka. Folia Primatologica 79: 324-325. https://doi.org/10.1159/000137690

Eschmann, C., R. Moore \& K.A.I. Nekaris (2008). Calling patterns 
of western purple-faced langurs (Mammalia: Primates: Cercopithecidea: Trachypithecus vetulus nestor) in a degraded human landscape in Sri Lanka. Contributions to Zoology 77: 57-65. https://doi.org/10.1163/18759866-07702001

Hladik, C.M. (1977). A comparative study of two sympatric species of leaf monkeys: Presbytis entellus and Presbytis senex, pp. 323-353. In: Clutton-Brock, T.H. (Ed.). Primate Ecology: Studies of Feeding and Ranging Behaviour in Lemurs, Monkeys, and Apes. Academic Press, London.

Jayasekara, P., U.R. Weerasinghe, S. Wijesundara \& S. Takatsuki (2007). Identifying diurnal and nocturnal frugivores in the terrestrial and arboreal layers of a tropical rain forest in Sri Lanka. Ecotropica 13: 7-15.

Moore, R.S., K.A.I. Nekaris \& C. Eschmann (2010). Habitat use by Western Purple-faced Langurs Trachypithecus vetulus nestor (Colobinae) in a fragmented suburban landscape. Endangered Species Research 12: 227-234. https://doi.org/10.3354/esr00307

Nahallage, C.A., M.A. Huffman, N. Kuruppu \& T. Weerasingha (2008). Diurnal primates in Sri Lanka and people's perception of them. Primate Conservation 23: 81-87. https://doi. org/10.1896/052.023.0109

Nekaris, K.A.I. \& G. de Silva Wijeyeratne (2007). The Primates of Sri Lanka. Sri Lanka Tourism Promotion Bureau and JetWing Holidays, Colombo, $152 \mathrm{pp}$.

Nekaris, K.A.I. \& V. Nijman (2008). Attention to Sri Lankan monkey paints a bleak picture yet gives glimmer of hope. Oryx 42: 487-488. https://doi.org/10.1017/S0030605308423141

Nekaris, K.A.I., A. Boulton \& V. Nijman (2013). An ethnoprimatological approach to assessing levels of tolerance between human and commensal non-human primates in Sri Lanka. Journal of Anthropological Sciences 91: 219-231. https://doi.org/10.4436/ jass.91008

Nijman, V. \& K.A.I. Nekaris (2010). Effects of deforestation on attitudes and levels of tolerance towards commensal primates (Cercopithecidae) in Sri Lanka. International Journal of Pest Management 56: 153-158. https://doi. org/10.1080/09670870903248850

Nijman, V. \& K.A.I. Nekaris (2013). Assessing conflict between humans and commensal non-human primates in Sri Lanka following an ethnoprimatological approach. Folia Primatologica 84: 307-308. https://doi.org/10.1159/000354129

Parker, L., V. Nijman \& K.A.I. Nekaris (2008). When there is no forest left: fragmentation, local extinction, and small population sizes in the Sri Lankan western purple-faced langur. Endangered Species Research 5: 29-36. https://doi.org/10.3354/esr00107

Rodrigo, M. (2011). Air rifles to take aim at protecting agriculture. Sunday Times, 22 May 2011.
Rudran, R. (1973). Adult male replacement in one-male troops of purple-faced langurs (Presbytis senex senex) and its effect on population structure. Folia Primatologica 19: 166-192. https://doi. org/10.1159/000155537

Rudran, R. (2008). A survey of Sri Lanka's Endangered and endemic Western Purple-faced Langur (Trachypithecus vetulus nestor). Primate Conservation 22: 139-144. https://doi. org/10.1896/052.022.0115

Rudran, R., H.S.K. Dayananda, D.D. Jayamanne \& D.G.R. Sirimanne (2013). Food habits and habitat use patterns of Sri Lanka's Western Purple-faced Langur. Primate Conservation 27: 99-108. https://doi. org/10.1896/052.027.0111

Rudran, R., S.C. de Mel, H.G. Salindra, K. Dayananda, R.M.R.R. Ratnayake, S. Weerakkody \& R.K. de Mel (2020a). An ethnoprimatological approach to conserving Sri Lanka's Critically Endangered western purple-faced langur. Primate Conservation 34: 227-233.

Rudran, R., W. Dittus, S.N. Gamage \& K.A.I. Nekaris (2020b). Semnopithecus vetulus ssp. nestor. The IUCN Red List of Threatened Species 2020: e.T39844A17988280. Downloaded on 5 May 2021. https://doi.org/10.2305/IUCN.UK.2020-2.RLTS.T39844A17988280. en

Rudran, R., S.J. Cabral de Mel, A. Sumanapala, R.K. de Mel \& K.K.T.I. Mahindarathna (2021). An ethnoprimatological approach to mitigating Sri Lanka's human-monkey conflicts. Primate Conservation 35: 1-10.

Sugathapala, D.G. \& S. Wijeweera (2011). Pros and cons of using air rifles in crop protection. Daily Mirror (Sri Lanka), 21 December 2011.

Vandercone, R.P., C. Dinadh, G. Wijethunga, K. Ranawana \& T.D. Rasmussen (2012). Dietary diversity and food selection in Hanuman langurs (Semnopithecus entellus) and purple-faced langurs (Trachypithecus vetulus) in the Kaludiyapokuna Forest Reserve in the dry zone of Sri Lanka. International Journal of Primatology 33: 1382-1405. https://doi.org/10.1007/s10764-012-9629-9

Weerakkody, W.A.D.S.N., D.K. Weerakoon \& M.R. Wijesinghe (2018) Group characteristics and home range size of the Western Purplefaced Langur (Semnopithecus vetulus nestor) in a human-modified landscape. WildLanka Journal of the Department of Wildlife Conservation of Sri Lanka 6: 37-47.

Westwood, W. (2018). Praying with Primates: The Impact of Buddhism on the Perceptions of Human-primate Interactions in Mihintale, Sri Lanka. MSc Thesis, Oxford Brookes University, Oxford, 57 pp.

Wijethilaka, S., L.S. Weerasekara, S. Bandara \& K.B. Ranawana (2021). Assessment of crop and property damage caused by Semnopithecus vetulus nestor (Bennett, 1833) (Mammalia: Primates: Cercopithecidae) in Gampaha District, Sri Lanka. Journal of Threatened Taxa 13: 18141-18147. https://doi.org/10.11609/ jott.6582.13.5.18141-18147 

Dr. John Noyes, Natural History Museum, London, UK

Dr. Albert G. Orr, Griffith University, Nathan, Australia

Dr. Sameer Padhye, Katholieke Universiteit Leuven, Belgium

Dr. Nancy van der Poorten, Toronto, Canada

Dr. Kareen Schnabel, NIWA, Wellington, New Zealand

Dr. R.M. Sharma, (Retd.) Scientist, Zoological Survey of India, Pune, India

Dr. Manju Siliwal, WILD, Coimbatore, Tamil Nadu, India

Dr. G.P. Sinha, Botanical Survey of India, Allahabad, India

Dr. K.A. Subramanian, Zoological Survey of India, New Alipore, Kolkata, India

Dr. P.M. Sureshan, Zoological Survey of India, Kozhikode, Kerala, India

Dr. R. Varatharajan, Manipur University, Imphal, Manipur, India

Dr. Eduard Vives, Museu de Ciències Naturals de Barcelona, Terrassa, Spain

Dr. James Young, Hong Kong Lepidopterists' Society, Hong Kong

Dr. R. Sundararaj, Institute of Wood Science \& Technology, Bengaluru, India

Dr. M. Nithyanandan, Environmental Department, La Ala Al Kuwait Real Estate. Co. K.S.C.,

Kuwait

Dr. Himender Bharti, Punjabi University, Punjab, India

Mr. Purnendu Roy, London, UK

Dr. Saito Motoki, The Butterfly Society of Japan, Tokyo, Japan

Dr. Sanjay Sondhi, TITLI TRUST, Kalpavriksh, Dehradun, India

Dr. Nguyen Thi Phuong Lien, Vietnam Academy of Science and Technology, Hanoi, Vietnam

Dr. Nitin Kulkarni, Tropical Research Institute, Jabalpur, India

Dr. Robin Wen Jiang Ngiam, National Parks Board, Singapore

Dr. Lional Monod, Natural History Museum of Geneva, Genève, Switzerland.

Dr. Asheesh Shivam, Nehru Gram Bharti University, Allahabad, India

Dr. Rosana Moreira da Rocha, Universidade Federal do Paraná, Curitiba, Brasi

Dr. Kurt R. Arnold, North Dakota State University, Saxony, Germany

Dr. James M. Carpenter, American Museum of Natural History, New York, USA

Dr. David M. Claborn, Missouri State University, Springfield, USA

Dr. Kareen Schnabel, Marine Biologist, Wellington, New Zealand

Dr. Amazonas Chagas Júnior, Universidade Federal de Mato Grosso, Cuiabá, Brasil

Mr. Monsoon Jyoti Gogoi, Assam University, Silchar, Assam, India

Dr. Heo Chong Chin, Universiti Teknologi MARA (UiTM), Selangor, Malaysia

Dr. R.J. Shiel, University of Adelaide, SA 5005, Australia

Dr. Siddharth Kulkarni, The George Washington University, Washington, USA

Dr. Priyadarsanan Dharma Rajan, ATREE, Bengaluru, India

Dr. Phil Alderslade, CSIRO Marine And Atmospheric Research, Hobart, Australia

Dr. John E.N. Veron, Coral Reef Research, Townsville, Australia

Dr. Daniel Whitmore, State Museum of Natural History Stuttgart, Rosenstein, Germany.

Dr. Yu-Feng Hsu, National Taiwan Normal University, Taipei City, Taiwan

Dr. Keith V. Wolfe, Antioch, California, USA

Dr. Siddharth Kulkarni, The Hormiga Lab, The George Washington University, Washington,

D.C., USA

Dr. Tomas Ditrich, Faculty of Education, University of South Bohemia in Ceske

Budejovice, Czech Republic

Dr. Mihaly Foldvari, Natural History Museum, University of Oslo, Norway

Dr. V.P. Uniyal, Wildlife Institute of India, Dehradun, Uttarakhand 248001, India

Dr. John T.D. Caleb, Zoological Survey of India, Kolkata, West Bengal, India

Dr. Priyadarsanan Dharma Rajan, Ashoka Trust for Research in Ecology and the Environment

(ATREE), Royal Enclave, Bangalore, Karnataka, India

\section{Fishes}

Dr. Neelesh Dahanukar, IISER, Pune, Maharashtra, India

Dr. Topiltzin Contreras MacBeath, Universidad Autónoma del estado de Morelos, México

Dr. Heok Hee Ng, National University of Singapore, Science Drive, Singapore

Dr. Rajeev Raghavan, St. Albert's College, Kochi, Kerala, India

Dr. Robert D. Sluka, Chiltern Gateway Project, A Rocha UK, Southall, Middlesex, UK

Dr. E. Vivekanandan, Central Marine Fisheries Research Institute, Chennai, India

Dr. Davor Zanella, University of Zagreb, Zagreb, Croatia

Dr. A. Biju Kumar, University of Kerala, Thiruvananthapuram, Kerala, India

Dr. Akhilesh K.V., ICAR-Central Marine Fisheries Research Institute, Mumbai Research

Centre, Mumbai, Maharashtra, India

Dr. J.A. Johnson, Wildlife Institute of India, Dehradun, Uttarakhand, India

Amphibians

Dr. Sushil K. Dutta, Indian Institute of Science, Bengaluru, Karnataka, India

Dr. Annemarie Ohler, Muséum national d'Histoire naturelle, Paris, France

\section{Reptiles}

Dr. Gernot Vogel, Heidelberg, Germany

Dr. Raju Vyas, Vadodara, Gujarat, India

Dr. Pritpal S. Soorae, Environment Agency, Abu Dubai, UAE.

Prof. Dr. Wayne J. Fuller, Near East University, Mersin, Turkey

Prof. Chandrashekher U. Rivonker, Goa University, Taleigao Plateau, Goa. India

Dr. S.R. Ganesh, Chennai Snake Park, Chennai, Tamil Nadu, India

Dr. Himansu Sekhar Das, Terrestrial \& Marine Biodiversity, Abu Dhabi, UAE
Birds

Dr. Hem Sagar Baral, Charles Sturt University, NSW Australia

Dr. Chris Bowden, Royal Society for the Protection of Birds, Sandy, UK

Dr. Priya Davidar, Pondicherry University, Kalapet, Puducherry, India

Dr. J.W. Duckworth, IUCN SSC, Bath, UK

Dr. Rajah Jayapal, SACON, Coimbatore, Tamil Nadu, India

Dr. Rajiv S. Kalsi, M.L.N. College, Yamuna Nagar, Haryana, India

Dr. V. Santharam, Rishi Valley Education Centre, Chittoor Dt., Andhra Pradesh, India

Dr. S. Balachandran, Bombay Natural History Society, Mumbai, India

Mr. J. Praveen, Bengaluru, India

Dr. C. Srinivasulu, Osmania University, Hyderabad, India

Dr. K.S. Gopi Sundar, International Crane Foundation, Baraboo, USA

Dr. Gombobaatar Sundev, Professor of Ornithology, Ulaanbaatar, Mongolia

Prof. Reuven Yosef, International Birding \& Research Centre, Eilat, Israel

Dr. Taej Mundkur, Wetlands International, Wageningen, The Netherlands

Dr. Carol Inskipp, Bishop Auckland Co., Durham, UK

Dr. Tim Inskipp, Bishop Auckland Co, Durham, UK

Dr. V. Gokula, National College, Tiruchirappalli, Tamil Nadu, India

Dr. Arkady Lelej, Russian Academy of Sciences, Vladivostok, Russia

Dr. Simon Dowell, Science Director, Chester Zoo, UK

Dr. Mário Gabriel Santiago dos Santos, Universidade de Trás-os-Montes e Alto Douro,

Quinta de Prados, Vila Real, Portugal

Dr. Grant Connette, Smithsonian Institution, Royal, VA, USA

Dr. M. Zafar-ul Islam, Prince Saud Al Faisal Wildlife Research Center, Taif, Saudi Arabia

Mammals

Dr. Giovanni Amori, CNR - Institute of Ecosystem Studies, Rome, Italy

Dr. Anwaruddin Chowdhury, Guwahati, India

Dr. David Mallon, Zoological Society of London, UK

Dr. Shomita Mukherjee, SACON, Coimbatore, Tamil Nadu, India

Dr. Angie Appel, Wild Cat Network, Germany

Dr. P.O. Nameer, Kerala Agricultural University, Thrissur, Kerala, India

Dr. Ian Redmond, UNEP Convention on Migratory Species, Lansdown, UK

Dr. Heidi S. Riddle, Riddle's Elephant and Wildlife Sanctuary, Arkansas, USA

Dr. Karin Schwartz, George Mason University, Fairfax, Virginia.

Dr. Lala A.K. Singh, Bhubaneswar, Orissa, India

Dr. Mewa Singh, Mysore University, Mysore, India

Dr. Paul Racey, University of Exeter, Devon, UK

Dr. Honnavalli N. Kumara, SACON, Anaikatty P.O., Coimbatore, Tamil Nadu, India

Dr. Nishith Dharaiya, HNG University, Patan, Gujarat, India

Dr. Spartaco Gippoliti, Socio Onorario Società Italiana per la Storia della Fauna "Giuseppe

Altobello", Rome, Italy

Dr. Justus Joshua, Green Future Foundation, Tiruchirapalli, Tamil Nadu, India

Dr. H. Raghuram, The American College, Madurai, Tamil Nadu, India

Dr. Paul Bates, Harison Institute, Kent, UK

Dr. Jim Sanderson, Small Wild Cat Conservation Foundation, Hartford, USA

Dr. Dan Challender, University of Kent, Canterbury, UK

Dr. David Mallon, Manchester Metropolitan University, Derbyshire, UK

Dr. Brian L. Cypher, California State University-Stanislaus, Bakersfield, CA

Dr. S.S. Talmale, Zoological Survey of India, Pune, Maharashtra, India

Prof. Karan Bahadur Shah, Budhanilakantha Municipality, Kathmandu, Nepal

Dr. Susan Cheyne, Borneo Nature Foundation International, Palangkaraja, Indonesia

Dr. Hemanta Kafley, Wildlife Sciences, Tarleton State University, Texas, USA

\section{Other Disciplines}

Dr. Aniruddha Belsare, Columbia MO 65203, USA (Veterinary)

Dr. Mandar S. Paingankar, University of Pune, Pune, Maharashtra, India (Molecular)

Dr. Jack Tordoff, Critical Ecosystem Partnership Fund, Arlington, USA (Communities)

Dr. Ulrike Streicher, University of Oregon, Eugene, USA (Veterinary)

Dr. Hari Balasubramanian, EcoAdvisors, Nova Scotia, Canada (Communities)

Dr. Rayanna Hellem Santos Bezerra, Universidade Federal de Sergipe, São Cristóvão, Brazil

Dr. Jamie R. Wood, Landcare Research, Canterbury, New Zealand

Dr. Wendy Collinson-Jonker, Endangered Wildlife Trust, Gauteng, South Africa

Dr. Rajeshkumar G. Jani, Anand Agricultural University, Anand, Gujarat, India

Dr. O.N. Tiwari, Senior Scientist, ICAR-Indian Agricultural Research Institute (IARI), New

Delhi, India

Dr. L.D. Singla, Guru Angad Dev Veterinary and Animal Sciences University, Ludhiana, India

Dr. Rupika S. Rajakaruna, University of Peradeniya, Peradeniya, Sri Lanka

Dr. Bahar Baviskar, Wild-CER, Nagpur, Maharashtra 440013, India

Reviewers 2018-2020

Due to pausity of space, the list of reviewers for $2018-2020$ is available online.

The opinions expressed by the authors do not reflect the views of the Journal of Threatened Taxa, Wildlife Information Liaison Development Society, Zoo Outreach Organization, or any of the partners. The journal, the publisher, the host, and the partners are not responsible for the accuracy of the political boundaries shown in the maps by the authors.

Journal of Threatened Taxa is indexed/abstracted in Bibliography of Systematic Mycology, Biological Abstracts, BIOSIS Previews, CAB Abstracts, EBSCO, Google Scholar, Index Copernicus, Index Fungorum, JournalSeek, National Academy of Agricultural Sciences, NewJour, OCLC WorldCat, SCOPUS, Stanford University Libraries, Virtual Library of Biology, Zoological Records.

NAAS rating (India) 5.64
Print copies of the Journal are available at cost. Write to:

The Managing Editor, JoTT,

c/o Wildlife Information Liaison Development Society,

No. 12, Thiruvannamalai Nagar, Saravanampatti - Kalapatti Road,

Saravanampatti, Coimbatore, Tamil Nadu 641035, India

ravi@threatenedtaxa.org 


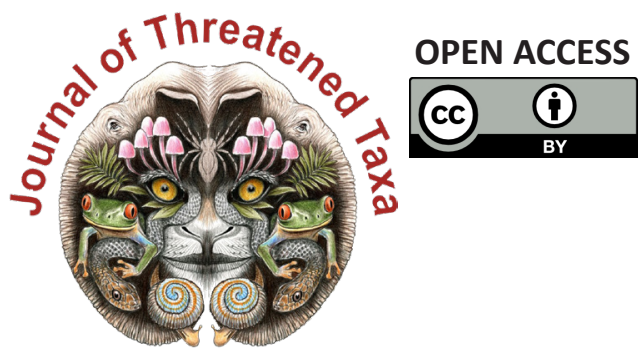

www.threatenedtaxa.org

The Journal of Threatened Taxa (JoTT) is dedicated to building evidence for conservation globally by publishing peer-reviewed articles online every month at a reasonably rapid rate at www.threatenedtaxa.org. All articles published in JoTT are registered under Creative Commons Attribution 4.0 International License unless otherwise mentioned. JoTT allows allows unrestricted use, reproduction, and distribution of articles in any medium by providing adequate credit to the author(s) and the source of publication.

\section{ISSN $0974-7907$ (Online) | ISSN $0974-7893$ (Print)}

\section{December 2021 | Vol. 13 | No. 14 | Pages: 20143-20310 \\ Date of Publication: 26 December 2021 (Online \& Print) DOI: 10.11609/jott.2021.13.14.20143-20310}

\section{Communications}

Updated distribution of seven Trichosanthes L. (Cucurbitales: Cucurbitaceae) taxa in India, along with taxonomic notes

Kanakasabapathi Pradheep, Soyimchiten, Ganjalagatta Dasaiah Harish, Muhammed Abdul Nizar, Kailash Chandra Bhatt, Anjula Pandey \& Sudhir Pal Ahlawat, Pp. 20143-20152

Dragonflies and Damselflies (Insecta: Odonata) of Aryanad Grama Panchayat, Kerala, India

- Reji Chandran \& A. Vivek Chandran, Pp. 20153-20166

Checklist of Odonata (Insecta) of Doon Valley, Uttarakhand, India

- Kritish De, Sarika Bhatt, Amar Paul Singh, Manisha Uniyal \& Virendra Prasad Uniyal, Pp. 20167-20173

Diversity of moths from the urban set-up of Valmiki Nagar, Chennai, India - Vikas Madhav Nagarajan, Rohith Srinivasan \& Mahathi Narayanaswamy, Pp. 20174-20189

Ichthyofaunal diversity with relation to environmental variables in the snowfed Tamor River of eastern Nepal

- Jawan Tumbahangfe, Jash Hang Limbu, Archana Prasad, Bhrarat Raj Subba \& Dil Kumar Limbu, Pp. 20190-20200

Observations on the foraging behavior of Tricoloured Munia Lonchura malacca (Linnaeus, 1766) and its interaction with pearl millet fields in Villupuram District, Tamil Nadu, India

- M. Pandian, Pp. 20201-20208

Roosting patterns of House Sparrow Passer domesticus Linn., 1758 (Aves: Passeridae) in Bhavnagar, Gujarat, India

- Foram P. Patel \& Pravinsang P. Dodia, Pp. 20209-20217

Review

Comprehensive checklist of algal class Chlorophyceae (sensu Fritsch, 1935) for Uttar Pradesh, India, with updated taxonomic status

- Sushma Verma, Kiran Toppo \& Sanjeeva Nayaka, Pp. 20218-20248

\section{View Point}

Wildlife managers ignore previous knowledge at great risk: the case of Rivaldo, the iconic wild Asian Elephant Elephas maximus L. of the Sigur Region, Nilgiri Biosphere Reserve, India

- Jean-Philippe Puyravaud \& Priya Davidar, Pp. 20249-20252

\section{Short Communications}

Diversity and distribution of macro lichens from Kalpetta Municipality of Wayanad District, Kerala, India

- Greeshma Balu, A.R. Rasmi, Stephen Sequeira \& Biju Haridas, Pp. 20253-20257

Extended distribution of two endemic epiphytes from the Western Ghats to the Deccan Plateau

- Sonali Vishnu Deore, Mangala Dala Sonawane \& Sharad Suresh Kambale, Pp. 20258-20260

Nomenclatural notes and report of Boehmeria penduliflora Wedd. ex D.G. Long from the Terai region of Uttar Pradesh, India

- Amit Gupta, Imtiyaz Ahmad Hurrah, Aparna Shukla \& Vijay V. Wagh, Pp. 2026120265
New distribution record of a true coral species, Psammocora contigua (Esper, 1794) from Gulf of Kachchh Marine National Park \& Sanctuary, India - R. Chandran, R. Senthil Kumaran, D.T. Vasavada, N.N. Joshi \& Osman G. Husen, Pp. 20266-20271

A new species of flat-headed mayfly Afronurus meenmutti (Ephemeroptera: Heptageniidae: Ecdyonurinae) from Kerala, India

- Marimuthu Muthukatturaja \& Chellaiah Balasubramanian, Pp. 20272-20277

Photographic record of Dholes predating on a young Banteng in southwestern Java, Indonesia

- Dede Aulia Rahman, Mochamad Syamsudin, Asep Yayus Firdaus, Herry Trisna Afriandi \& Anggodo, Pp. 20278-20283

Latrine site and its use pattern by Large Indian Civet Viverra zibetha Linnaeus, 1758: record from camera trap

- Bhuwan Singh Bist, Prashant Ghimire, Basant Sharma, Chiranjeevi Khanal \& Anoj Subedi, Pp. 20284-20287

Notes

Two additions to the flora of Kerala, India

- P. Murugan, Basil Paul \& M. Sulaiman, Pp. 20288-20291

Pentatropis R.Br. ex Wight \& Arn. (Apocynaceae), a new generic record for Kerala, India

- V. Ambika, Jose Sojan \& V. Suresh, Pp. 20292-20294

New record of Kashmir Birch Mouse Sicista concolor leathemi (Thomas, 1893) (Rodentia: Sminthidae) in the Indian Himalaya

- S.S. Talmale, Avtar Kaur Sidhu \& Uttam Saikia, Pp. 20295-20298

Breeding record of Black-headed Ibis Threskiornis melanocephalus (Aves: Threskiornithidae) at Mavoor wetland, Kozhikode District, Kerala, India - C.T. Shifa, Pp. 20299-20301

\section{Response}

Crop and property damage caused by Purple-faced Langurs Trachypithecus vetulus (Mammalia: Primates: Cercopithecidae) - Vincent Nijman, Pp. 20302-20306

Reply

If habitat heterogeneity is effective for conservation of butterflies in urban landscapes of Delhi, India? Unethical publication based on data manipulation: Response of original authors

- Monalisa Paul \& Aisha Sultana, Pp. 20307-20308

\section{Book Review}

Freshwater fishes of the Arabian Peninsula - Rajeev Raghavan, Pp. 20309-20310

Publisher \& Host

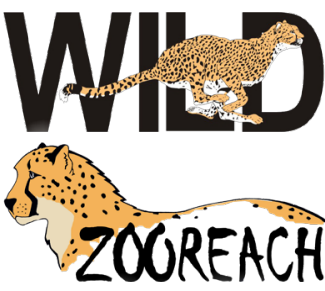

Threatened Taxa 